\title{
Chronic Heroin Self-Administration Desensitizes $\mu$ Opioid Receptor-Activated G-Proteins in Specific Regions of Rat Brain
}

\author{
Laura J. Sim-Selley, ${ }^{1}$ Dana E. Selley, ${ }^{1}$ Leslie J. Vogt, ${ }^{2}$ Steven R. Childers, ${ }^{2}$ and Thomas J. Martin ${ }^{2}$ \\ ${ }^{1}$ Department of Pharmacology and Toxicology, and Institute for Drug and Alcohol Studies, Virginia Commonwealth \\ University Medical College of Virginia, Richmond, Virginia 23298, and 2Department of Physiology/Pharmacology, and \\ Center for the Neurobiological Investigation of Drug Abuse, Wake Forest University School of Medicine, Winston-Salem, \\ North Carolina 27157
}

In previous studies from our laboratory, chronic noncontingent morphine administration decreased $\mu$ opioid receptor-activated G-proteins in specific brainstem nuclei. In the present study, $\mu$ opioid receptor binding and receptor-activated G-proteins were examined after chronic heroin self-administration. Rats were trained to self-administer intravenous heroin for up to $39 \mathrm{~d}$, achieving heroin intake up to $366 \mathrm{mg} \cdot \mathrm{kg}^{-1} \cdot \mathrm{d}^{-1} \cdot \mu$ opioidstimulated $\left[{ }^{35} \mathrm{~S}\right] \mathrm{GTP} \gamma \mathrm{S}$ and $\left[{ }^{3} \mathrm{H}\right]$ naloxone autoradiography were performed in adjacent brain sections. Agonist-stimulated $\left[{ }^{35} \mathrm{~S}\right] \mathrm{GTP} \gamma \mathrm{S}$ autoradiography also examined other G-proteincoupled receptors, including $\delta$ opioid, ORL-1, GABA $A_{B}$, adenosine $A_{1}$, cannabinoid, and $5-H_{1} T_{1 A}$. In brains from heroin selfadministering rats, decreased $\mu$ opioid-stimulated $\left[{ }^{35} \mathrm{~S}\right] \mathrm{GTP} \gamma \mathrm{S}$ binding was observed in periaqueductal gray, locus coeruleus, lateral parabrachial nucleus, and commissural nucleus tractus solitarius, as previously observed in chronic morphine-treated animals. In addition, decreased $\mu$ opioid-stimulated [ $\left.{ }^{35} \mathrm{~S}\right] \mathrm{GTP} \gamma \mathrm{S}$

Chronic abuse of heroin remains a major problem: the ability of heroin to produce high levels of tolerance and physical dependence, combined with its reinforcing properties, create a chronic relapsing disease with a significant fatality rate (Goldstein and Herrera, 1995). The acute CNS effects of heroin (3,6-diacetylmorphine) are primarily mediated by the binding of its metabolites, 6-monoacetylmorphine (6-MAM) and morphine, to $\mu$ opioid receptors (Umans and Inturrisi, 1981; Inturrisi et al., 1983), although recent evidence also suggests the potential existence of specific receptors for heroin or its metabolites (Rossi et al., 1997; Schuller et al., 1999). $\mu$ opioid receptors are located in brain regions known to mediate the acute actions of opiates (Young and Kuhar, 1979; Herkenham and Pert, 1982), which include reinforcement, analgesia, sympathetic nervous system effects, and respiratory depression. Chronic opiate administration leads to the development of tolerance and physical dependence on most opiate-mediated effects, although the rate and magnitude of the development of these chronic effects vary among different symptoms (Way et al., 1969).

\footnotetext{
Received Nov. 15, 1999; revised March 8, 2000; accepted March 29, 2000.

This work was supported by Public Health Service Grants DA-00287 (L.J.S.), DA-10770 (D.E.S.), DA-06634 (S.R.C.), and DA-00247 (T.J.M.) from the National Institute on Drug Abuse. C. Todd Hairston and Ruoyu Xiao provided technical assistance.

Correspondence should be addressed to Dr. Steven R. Childers, Center for Investigative Neuroscience, Wake Forest University School of Medicine, Medical Center Boulevard, Winston-Salem, NC 27157. E-mail: childers@wfubmc.edu. Copyright (C) 2000 Society for Neuroscience $0270-6474 / 00 / 124555-08 \$ 15.00 / 0$
}

binding was found in thalamus and amygdala after heroin selfadministration. Despite this decrease in $\mu$-activated G-proteins, $\left[{ }^{3} \mathrm{H}\right]$ naloxone binding demonstrated increased $\mu$ opioid receptor binding in several brain regions after heroin self-administration, and there was a significant decrease in $\mu$ receptor G-protein efficiency as expressed as a ratio between agonist-activated G-proteins and $\mu$ receptor binding. No effects on agoniststimulated [ $\left.{ }^{35} \mathrm{~S}\right] \mathrm{GTP} \gamma \mathrm{S}$ binding were found for any other receptor examined. The effect of chronic heroin self-administration to decrease $\mu$-stimulated $\left[{ }^{35}\right.$ S] GTP $\gamma S$ binding varied between regions and was highest in brainstem and lowest in the cortex and striatum. These results not only provide potential neuronal mechanisms that may contribute to opioid tolerance and dependence, but also may explain why various chronic effects of opioids develop to different degrees.

Key words: $\mu$ opioid receptor; heroin; G-protein; desensitization; $\delta$ opioid receptor; nociceptin/orphanin FQ receptor
Despite numerous investigations, the neuronal basis of opiate tolerance and dependence remains unclear. Opioid receptors belong to the family of inhibitory G-protein-coupled receptors (Evans et al., 1992; Kieffer et al., 1992; Chen et al., 1993; Thompson et al., 1993), and chronic opiate exposure in cultured cell lines results in desensitization followed by receptor downregulation (Law et al., 1983; Puttfarcken and Cox, 1989; Breivogel et al., 1997). However, previous studies in animals have produced conflicting results regarding the effects of chronic opiate administration on opioid receptor number (Klee and Streaty, 1974; Tao et al., 1987; Brady et al., 1989; Yoburn et al., 1993), and it has been suggested that many of the cellular adaptations underlying tolerance and dependence occur at the level of the signal transducing G-protein (Blasig et al., 1979; Tao et al., 1993) or by compensatory mechanisms involving downstream effectors (Nestler, 1992; Noble and Cox, 1996, 1997).

The development of agonist-stimulated $\left[{ }^{35} \mathrm{~S}\right] \mathrm{GTP} \gamma \mathrm{S}$ binding for opioid receptors (Traynor and Nahorski, 1995) has provided an opportunity not only to determine acute mechanisms of agonist efficacy (Clark et al., 1997; Selley et al., 1997b; Alt et al., 1998; Selley et al., 1998) but also to examine effects of chronic agonist treatment on coupling of receptors to G-proteins (Breivogel et al., 1997; Selley et al., 1997a). In brain, this technique has been extended by the development of $\left[{ }^{35} \mathrm{~S}\right] \mathrm{GTP} \gamma \mathrm{S}$ autoradiography (Sim et al., 1995), which allows the visualization of receptoractivated G-proteins in brain sections. Using this technique, our laboratory (Sim et al., 1996a) showed previously that 
chronic morphine administration decreased $\mu$ opioid-activated G-proteins in specific nuclei in brainstem, but not in forebrain structures thought to contribute to the reinforcing effects of opiates (Bozarth and Wise, 1984; Vaccarino et al., 1985). These results suggested that although $\mu$ opioid receptor desensitization occurs after chronic morphine administration, cellular adaptations may depend on the brain region examined. The present study was designed to extend those results by determining the effects of heroin self-administration on opioid receptors and receptor-activated G-proteins in brain.

\section{MATERIALS AND METHODS}

Materials. Male Fischer 344 rats (250-300 gm) were purchased from Harlan Laboratories (Indianapolis, IN). $\left[{ }^{35} \mathrm{~S}\right] \mathrm{GTP} \gamma \mathrm{S}(1250 \mathrm{Ci} / \mathrm{mmol})$ and $\left[{ }^{3} \mathrm{H}\right]$ naloxone $(48 \mathrm{Ci} / \mathrm{mmol})$ were purchased from New England $\mathrm{Nu}-$ clear (Boston, MA). [D-Ala ${ }^{2}, N$-Me-Phe ${ }^{4}, \mathrm{Gly}^{5}$-ol]-enkephalin (DAMGO) was obtained from Peninsula Laboratories (Belmont, CA). R(+)-baclofen $\mathrm{HCl}, \mathrm{R}(+)$-WIN 55,212-2 mesylate, 5-carboxamidotryptamine maleate (5-CT), and R(-)N6-(2-phenylisopropyl)adenosine (PIA) were purchased from Research Biochemicals International (Natick, MA). Adenosine deaminase, $p$-Cl-[D-penicillamine ${ }^{2,5}, p$-Cl-Phe $\left.{ }^{4}\right]$ enkephalin ( $p$-Cl-DPDPE), and GDP were obtained from Sigma (St. Louis, MO). The nociceptin/ orphanin FQ (N/OFQ) peptide was synthesized in the Protein Core Laboratory of the Cancer Center at Wake Forest University. Reflections autoradiography film was purchased from New England Nuclear. Heroin hydrochloride was provided by Research Triangle Institute (Research Triangle Park, NC) through the Drug Supply Program of the National Institute on Drug Abuse. All doses are reported in terms of the free base of heroin. Pentobarbital (Nembutal) was purchased from Abbott Laboratories (North Chicago, IL) in a vehicle of 10:40:50 ethanol/propylene glycol/water at a concentration of $50 \mathrm{mg} / \mathrm{ml}$. Atropine sulfate was purchased from Sigma, and heparin was purchased from Elkins-Sinn (Cherry Hill, NJ). All other reagent grade chemicals were obtained from Sigma or Fisher Scientific (Pittsburgh, PA).

Heroin self-administration. Male Fischer 344 rats were implanted with chronic indwelling catheters for intravenous administration of drugs as described previously (Martin et al., 1995). Control rats were subjected to the same surgery and catheters as drug-treated rats. After recovery from surgery, animals were trained to self-administer intravenous inf usions of $0.06 \mathrm{mg} / \mathrm{kg}$ heroin during daily $4 \mathrm{hr}$ sessions on a fixed-ratio 10 schedule of reinforcement (Martin et al., 1995). Once drug intake was stable $(\sim 1$ $\left.\mathrm{mg} \cdot \mathrm{kg}^{-1} \cdot \mathrm{d}^{-1}\right)$, this dose of heroin was made available for selfadministration $24 \mathrm{hr} / \mathrm{d}$. The schedule for increasing heroin doses, determined from the rate of drug self-administration until the final infusion rate $(6 \mathrm{mg} / \mathrm{kg})$ produced intakes of up to $366 \mathrm{mg} \cdot \mathrm{kg}^{-1} \cdot \mathrm{d}^{-1}$, is presented in Results. The rats were maintained on this schedule of increasing heroin doses for 29-39 d. Animals were killed after 5 d of selfadministration of $6 \mathrm{mg} / \mathrm{kg}$ of heroin, during which time total heroin intake did not vary by $>10 \%$ of the mean for each animal.

Rats were decapitated, and brains were removed and frozen in isopentane at $-35^{\circ}$. Coronal sections $(20 \mu \mathrm{m})$ were cut throughout the rostral-caudal extent of the brain on a cryostat maintained at $-20^{\circ}$, mounted on gelatin-subbed slides, and stored at $-80^{\circ}$ until processed as described below.

Agonist-stimulated $\left[{ }^{35} S\right] G T P \gamma S$ autoradiography in brain sections. Agonist-stimulated $\left[{ }^{35} \mathrm{~S}\right] \mathrm{GTP} \gamma \mathrm{S}$ autoradiography was performed as described previously (Sim et al., 1995). Sections were rinsed in TME buffer (50 mm Tris-HCl, 3 mm $\mathrm{MgCl}_{2}, 0.2 \mathrm{~mm}$ EGTA, $100 \mathrm{~mm} \mathrm{NaCl}, \mathrm{pH} 7.4$ ) at $25^{\circ}$ for $10 \mathrm{~min}$, followed by a $15 \mathrm{~min}$ preincubation in TME buffer containing $2 \mathrm{~mm}$ GDP and adenosine deaminase $(9.5 \mathrm{mU} / \mathrm{ml})$ at $25^{\circ}$. Sections were then incubated in TME buffer with GDP, adenosine deaminase, $0.04 \mathrm{~nm}\left[{ }^{35} \mathrm{~S}\right] \mathrm{GTP} \gamma \mathrm{S}$, and appropriate agonist at $25^{\circ}$ for $2 \mathrm{hr}$. The following agonists were used: $10 \mu \mathrm{M}$ DAMGO ( $\mu$ opioid), $10 \mu \mathrm{M}$ $p$-Cl-DPDPE ( $\delta$ opioid), $3 \mu$ M N/OFQ, $10 \mu$ M WIN 55212-2 (cannabinoid), $300 \mu \mathrm{M}$ baclofen $\left(\mathrm{GABA}_{\mathrm{B}}\right.$ ), $1 \mu \mathrm{M}$ PIA (adenosine $\mathrm{A}_{1}$ ), or $2 \mu$ M 5-CT $\left(5 \mathrm{HT}_{1 \mathrm{~A}}\right)$. Sections incubated with N/OFQ contained protease inhibitors, and those incubated with WIN 55,212-2 contained bovine serum albumin, as described previously (Sim et al., 1995, 1996c). Slides were rinsed twice for $2 \mathrm{~min}$ each in cold Tris buffer $(50 \mathrm{~mm}$ Tris- $\mathrm{HCl}, \mathrm{pH}$ 7.4) and once in deionized $\mathrm{H}_{2} \mathrm{O}$. Slides were dried overnight and exposed to film for $48 \mathrm{hr}$ in film cassettes containing $\left[{ }^{14} \mathrm{C}\right]$ microscales (Amersham, Arlington Heights, IL) for densitometric analysis.

$\left[{ }^{3} H\right]$ Naloxone autoradiography. Sections were equilibrated in TME

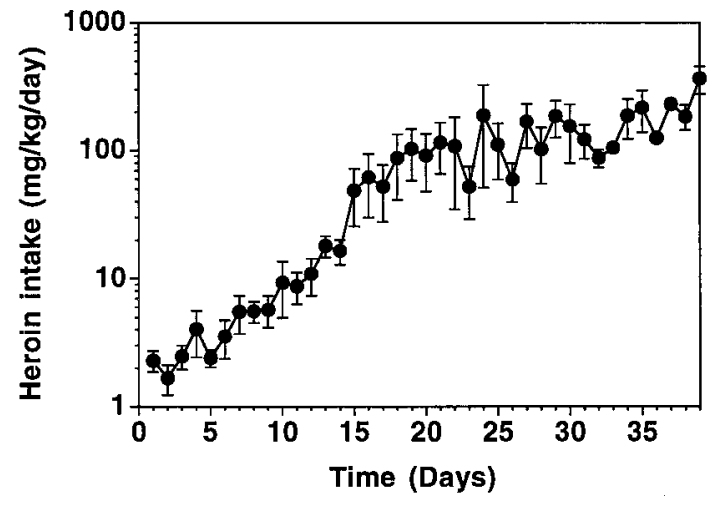

Figure 1. Heroin intake in self-administering animals. Rats were initially trained to self-administer intravenous infusions of $0.06 \mathrm{mg} / \mathrm{kg}$ heroin during daily $4 \mathrm{hr}$ sessions on a fixed-ratio 10 schedule of reinforcement. As drug intake became stable and began to increase, the dose of heroin was gradually increased to $6 \mathrm{mg} \cdot \mathrm{kg}^{-1} \cdot \mathrm{d}^{-1}$ as described in Results. Data are mean values \pm SEM of daily heroin intake in eight rats.

buffer for $15 \mathrm{~min}$ at $25^{\circ}$. Slides were then incubated in $2 \mathrm{nM}\left[{ }^{3} \mathrm{H}\right]$ naloxone in TME buffer containing $1 \mu \mathrm{M} p$-Cl-DPDPE (to block $\delta$ receptors) for $1 \mathrm{hr}$ at $25^{\circ}$. Slides were rinsed three times for $2 \mathrm{~min}$ each in $50 \mathrm{~mm}$ Tris buffer at $4^{\circ} \mathrm{C}$, then briefly in deionized $\mathrm{H}_{2} \mathrm{O}$ at $4^{\circ}$. Nonspecific binding was assessed in the presence of $10 \mu \mathrm{M}$ levallorphan. Slides were dried under a cool stream of air and exposed to Hyperfilm- ${ }^{3} \mathrm{H}$ for $\sim 8$ weeks. All film cassettes included a $\left[{ }^{3} \mathrm{H}\right]$ microscale (Amersham) for calibration of results.

Analysis of data. Films were digitized with a Sony XC-77 video camera and analyzed densitometrically using the NIH IMAGE program for Macintosh computers. For $\left[{ }^{35} \mathrm{~S}\right] \mathrm{GTP} \gamma \mathrm{S}$ autoradiography, resulting values were expressed as nanocuries of $\left[{ }^{35} \mathrm{~S}\right]$ per gram of tissue and were corrected for $\left[{ }^{35} \mathrm{~S}\right]$ from $\left[{ }^{14} \mathrm{C}\right]$ standards based on incorporation of $\left[{ }^{35} \mathrm{~S}\right]$ into sections of frozen brain paste, as described previously (Sim et al., 1997). Net agonist-stimulated $\left[{ }^{35} \mathrm{~S}\right] \mathrm{GTP} \gamma \mathrm{S}$ binding was calculated by subtracting basal binding (obtained in the absence of agonist) from agonist-stimulated binding. For $\left[{ }^{3} \mathrm{H}\right]$ naloxone binding, nonspecific binding was densitometrically subtracted from total binding before analysis, and resulting values represent specific nanocuries per gram of $\left[{ }^{3} \mathrm{H}\right]$ naloxone binding. Data are reported as mean values \pm SE of triplicate sections of brains from eight treated and seven control animals. Statistical comparison between control and heroin self-administering rats was performed by ANOVA followed by post hoc analysis using the two-tailed non-paired Student's $t$ test.

\section{RESULTS}

\section{Heroin self-administration}

To produce opiate tolerance and dependence using a procedure that parallels the behavior of chronic opiate use in humans, the current study established a paradigm of heroin self-administration in rats. The results of this procedure are illustrated in Figure 1, which shows daily heroin intake for self-administering animals over the course of the study. In daily $4 \mathrm{hr}$ sessions, animals were trained to self-administer intravenous infusions of $0.06 \mathrm{mg} / \mathrm{kg}$ heroin on a fixed-ratio 10 schedule of reinforcement (Martin et al., 1995). The dose of heroin was increased as drug intake escalated across several days, thereby allowing the animals to maintain high levels of daily heroin intake and still have time for feeding and sleeping. Beginning with a dose of $0.06 \mathrm{mg} / \mathrm{kg}$ per infusion, heroin intake increased from an average of $1.8 \pm 0.33$ $\mathrm{mg} \cdot \mathrm{kg}^{-1} \cdot \mathrm{d}^{-1}$ to $5.1 \pm 1.6 \mathrm{mg} \cdot \mathrm{kg}^{-1} \cdot \mathrm{d}^{-1}$ over the next $7.6 \pm$ $1.1 \mathrm{~d}$. The dose of heroin was subsequently increased to $0.3 \mathrm{mg} / \mathrm{kg}$ per infusion. Animals compensated for the dose increase by taking fewer infusions; however, daily heroin intake again increased from $5.6 \pm 0.93 \mathrm{mg} \cdot \mathrm{kg}^{-1} \cdot \mathrm{d}^{-1}$ to $16.9 \pm 3.7$ $\mathrm{mg} \cdot \mathrm{kg}^{-1} \cdot \mathrm{d}^{-1}$ over an average of $6.9 \pm 1.1 \mathrm{~d}$. The dose of heroin 


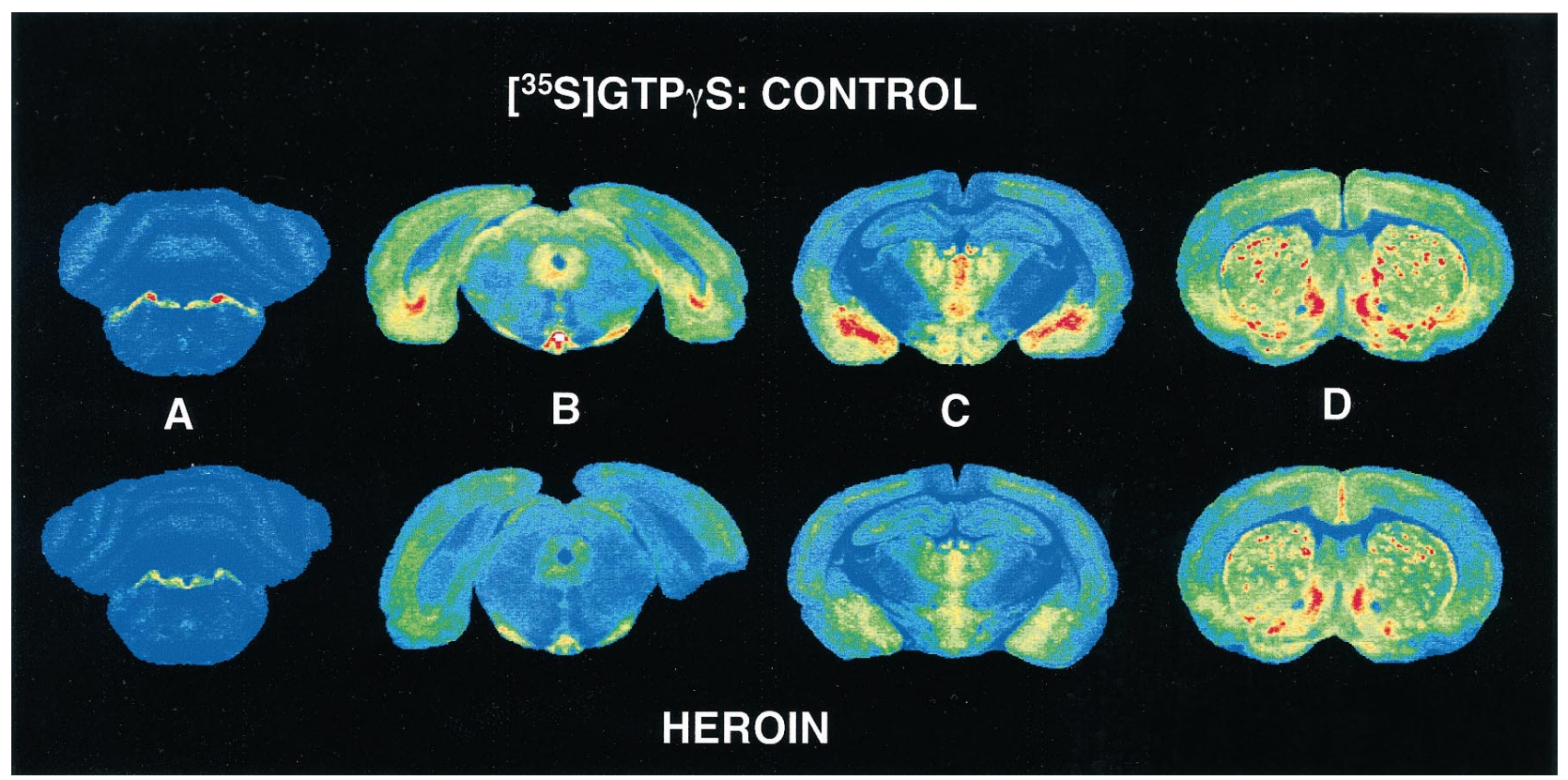

Figure 2. Representative autoradiograms showing $\mu$ opioid-stimulated $\left[{ }^{35} \mathrm{~S}\right] \mathrm{GTP} \gamma \mathrm{S}$ binding in coronal brain sections from control and heroin self-administering rats. Decreases in DAMGO-stimulated $\left[{ }^{35} \mathrm{~S}\right] \mathrm{GTP} \gamma \mathrm{S}$ binding are evident in nuclei in sections from heroin-treated rats, including locus coeruleus $(A)$, periaqueductal gray/interpeduncular nucleus $(B)$, and thalamus/amygdala $(C)$, but not caudate putamen/nucleus accumbens/cingulate cortex $(D)$.

was then increased to $1.2 \mathrm{mg} / \mathrm{kg}$ per infusion, and daily drug intake subsequently increased from $16.2 \pm 2.8 \mathrm{mg} \cdot \mathrm{kg}^{-1} \cdot \mathrm{d}^{-1}$ to $81.4 \pm 17.0 \mathrm{mg} \cdot \mathrm{kg}^{-1} \cdot \mathrm{d}^{-1}$ over $8.8 \pm 1.8 \mathrm{~d}$. The dose of heroin was finally increased to $6 \mathrm{mg} / \mathrm{kg}$ per infusion, and daily heroin intake reached a maximum of $366 \mathrm{mg} \cdot \mathrm{kg}^{-1} \cdot \mathrm{d}^{-1}$, with animals maintaining self-administration for 29-39 d. The tolerance produced by this paradigm is illustrated by the fact that this daily heroin intake was lethal in drug-naive animals. Moreover, these animals were also highly dependent, because interruption of drug intake produced significant withdrawal symptoms (ptosis, diarrhea, vocalization) soon after drug cessation in five animals that were not included in the autoradiographic studies (data not shown).

\section{Autoradiography of $\mu$ opioid-stimulated $\left[{ }^{35} \mathrm{~S}\right] \mathrm{GTP} \gamma \mathrm{S}$ binding and $\left[{ }^{3} \mathrm{H}\right]$ naloxone binding}

Coronal sections from several brain levels were processed for DAMGO-stimulated $\left[{ }^{35} \mathrm{~S}\right] \mathrm{GTP} \gamma \mathrm{S}$ binding and $\left[{ }^{3} \mathrm{H}\right]$ naloxone binding to examine $\mu$ opioid-activated G-proteins and $\mu$ receptors, respectively. The use of $\left[{ }^{3} \mathrm{H}\right]$ naloxone along with DAMGOstimulated $\left[{ }^{35} \mathrm{~S}\right] \mathrm{GTP} \gamma \mathrm{S}$ autoradiography allows both parameters to be determined under similar assay conditions and provides direct comparison between receptor binding and activation of G-proteins. Representative sections of DAMGO-stimulated $\left[{ }^{35} \mathrm{~S}\right] \mathrm{GTP} \gamma \mathrm{S}$ binding from control and chronic heroin selfadministering rats are shown in Figure 2. Figure 2, $A$ and $B$, shows autoradiograms at the level of locus coeruleus $(A)$ and periaqueductal gray/interpeduncular nucleus $(B)$, regions in which decreased DAMGO-stimulated $\left[{ }^{35} \mathrm{~S}\right] \mathrm{GTP} \gamma \mathrm{S}$ binding was evident in our previous study of chronic morphine-treated rats (Sim et al., 1996a). In sections from control rats, high levels of $\mu$ receptor-activated G-proteins were observed in these brainstem nuclei. However, in sections from chronic heroin self-administering rats, $\mu$ receptor-stimulated G-protein activity was visibly reduced in these regions. Figure $2 C$ shows autoradiograms of thalamus, amygdala, and hypothalamus, where decreases in DAMGOstimulated $\left[{ }^{35} \mathrm{~S}\right] \mathrm{GTP} \gamma \mathrm{S}$ binding in sections from heroin selfadministering rats were particularly evident in the medial thalamus and amygdala, with a magnitude of decrease similar to that observed in brainstem. These data are in contrast to the previous study using chronic morphine-treated rats, where none of these regions displayed any decrease in $\mu$-stimulated $\left[{ }^{35} \mathrm{~S}\right] \mathrm{GTP} \gamma \mathrm{S}$ binding after chronic morphine treatment (Sim et al., 1996a). On the other hand, only a small decrease was seen in caudate putamen, cingulate cortex, and nucleus accumbens from heroin selfadministering rats (Fig. $2 D$ ).

The anatomical distribution of $\left[{ }^{3} \mathrm{H}\right]$ naloxone binding was the same as that seen for DAMGO-stimulated $\left[{ }^{35} \mathrm{~S}\right] \mathrm{GTP} \gamma \mathrm{S}$ binding. Representative sections in Figure 3 (which show adjacent sections from the same animals presented in Fig. 2) show an increase in $\left[{ }^{3} \mathrm{H}\right]$ naloxone binding in several regions of heroin self-administration versus control brains; these regions include locus coeruleus (Fig. 3A), periaqueductal gray/interpeduncular nucleus (Fig. 3B), and hypothalamus (Fig. 3C). Little visible change was apparent was in the amygdala, thalamus (Fig. $3 C$ ), caudate putamen, or cingulate cortex (Fig. $3 D$ ) from heroin self-administering rats.

Quantification of basal and agonist-stimulated $\left[{ }^{35} \mathrm{~S}\right] \mathrm{GTP} \gamma \mathrm{S}$ binding, and specific $\left[{ }^{3} \mathrm{H}\right]$ naloxone binding, was obtained by measuring optical density in autoradiograms of regions of interest. Basal $\left[{ }^{35} \mathrm{~S}\right] \mathrm{GTP} \gamma \mathrm{S}$ binding was generally unaffected by chronic heroin self-administration (data not shown), except in the interpeduncular nucleus and locus coeruleus, where heroin selfadministration significantly decreased basal $\left[{ }^{35} \mathrm{~S}\right] \mathrm{GTP} \gamma \mathrm{S}$ binding by 18 and $20 \%$, respectively $(p<0.05)$. This finding confirms previous observations of decreased basal $\left[{ }^{35} \mathrm{~S}\right] \mathrm{GTP} \gamma \mathrm{S}$ binding in the locus coeruleus of chronic morphine-treated rats (Sim et al., 1996a; Selley et al., 1997a).

Table 1 shows the analysis of net DAMGO-stimulated $\left[{ }^{35} \mathrm{~S}\right]$ GTP $\gamma \mathrm{S}$ binding and specific $\left[{ }^{3} \mathrm{H}\right]$ naloxone binding from both 


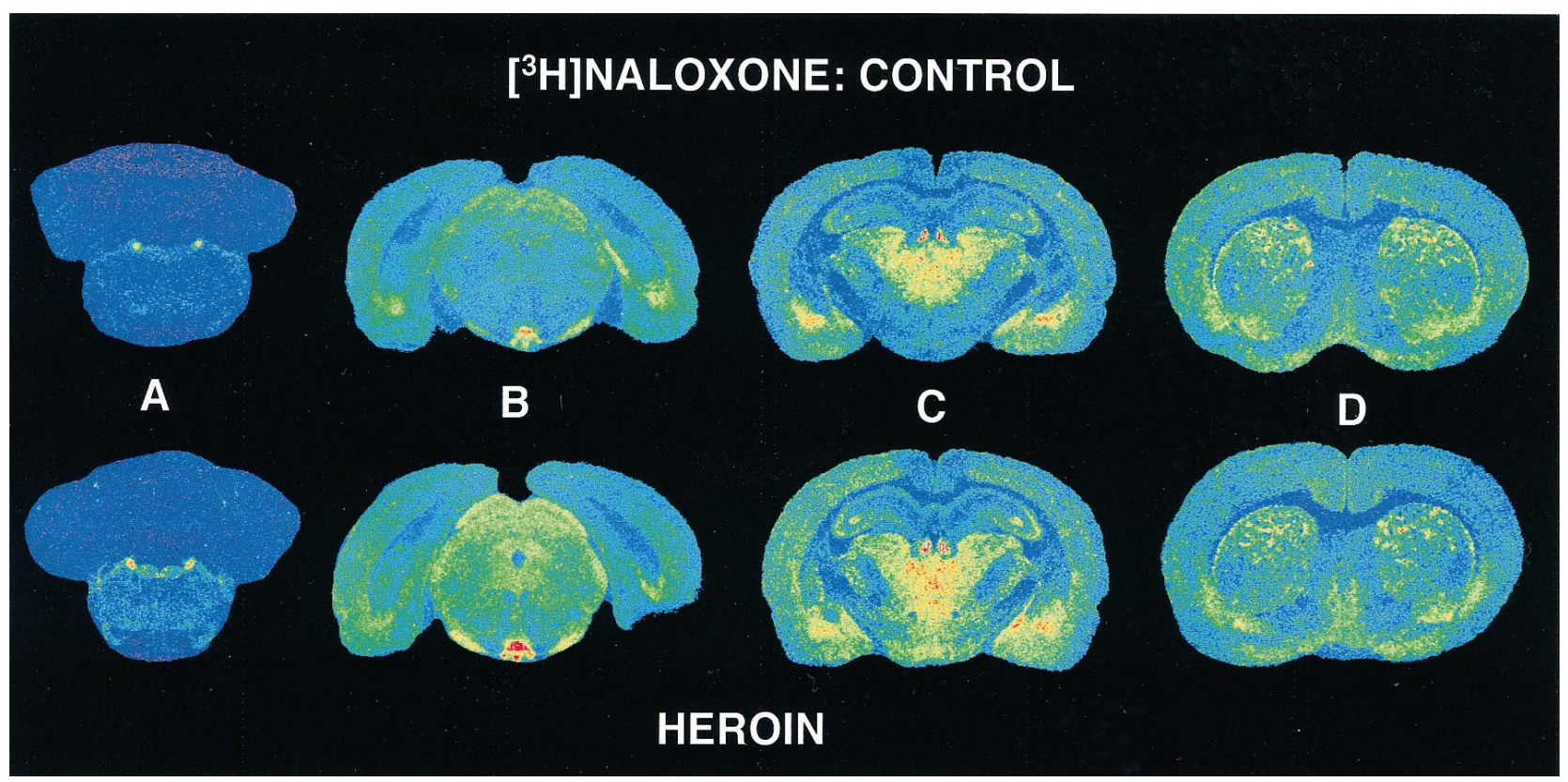

Figure 3. Representative autoradiograms showing $\left[{ }^{3} \mathrm{H}\right]$ naloxone binding in control and heroin self-administering rats. Sections are at the same levels and from the same animals as those in Figure 2. Increases in $\left[{ }^{3} \mathrm{H}\right]$ naloxone binding are evident in sections from heroin-treated rats in regions including locus coeruleus $(A)$, periaqueductal gray/interpeduncular nucleus $(B)$, and hypothalamus $(C)$ but not thalamus/amygdala $(C)$ or caudate putamen $(D)$.

Table 1. Effect of chronic heroin self-administration on $\mu$ opioid-stimulated $\left[{ }^{35} \mathrm{~S}\right] \mathrm{GTP} \gamma \mathrm{S}$ binding and $\left[{ }^{3} \mathrm{H}\right]$ naloxone binding in rat brain

\begin{tabular}{|c|c|c|c|c|}
\hline \multirow[b]{2}{*}{ Region } & \multicolumn{2}{|c|}{$\begin{array}{l}\text { Net } \mu \text {-stimulated } \\
{\left[{ }^{35} \mathrm{~S}\right] \mathrm{GTP} \gamma \mathrm{S} \text { binding (nCi/gm) }}\end{array}$} & \multicolumn{2}{|c|}{$\left[{ }^{3} \mathrm{H}\right]$ naloxone binding $(\mathrm{nCi} / \mathrm{gm})$} \\
\hline & Control & Heroin (\% change) & Control & Heroin ( $\%$ change) \\
\hline Prefrontal cortex & $250 \pm 22$ & $268 \pm 12$ & $363 \pm 6$ & $401 \pm 7^{*}(+10)$ \\
\hline Cingulate cortex & $332 \pm 18$ & $293 \pm 18$ & $570 \pm 14$ & $620 \pm 10^{* *}(+9)$ \\
\hline Rostral nucleus accumbens & $620 \pm 16$ & $509 \pm 12 *(-18)$ & $923 \pm 73$ & $1004 \pm 83(+10)$ \\
\hline Nucleus accumbens & $417 \pm 19$ & $370 \pm 13$ & $730 \pm 16$ & $804 \pm 17^{* *}(+10)$ \\
\hline Caudate putamen & $407 \pm 20$ & $372 \pm 12$ & $642 \pm 14$ & $680 \pm 12$ \\
\hline Amygdala & $438 \pm 25$ & $299 \pm 22 *(-32)$ & $386 \pm 11$ & $413 \pm 7$ \\
\hline Hippocampus & $76 \pm 11$ & $61 \pm 10$ & $229 \pm 5$ & $243 \pm 3^{* * *}(+6)$ \\
\hline Medial thalamus & $603 \pm 33$ & $435 \pm 30 *(-28)$ & $488 \pm 15$ & $507 \pm 13$ \\
\hline Mediodorsal thalamus & $531 \pm 34$ & $386 \pm 25 *(-27)$ & $389 \pm 8$ & $383 \pm 10$ \\
\hline Hypothalamus & $226 \pm 14$ & $188 \pm 22$ & $281 \pm 7$ & $356 \pm 13^{*}(+27)$ \\
\hline Ventral tegmental area & $123 \pm 21$ & $113 \pm 15$ & ND & \\
\hline Interpeduncular nucleus & $618 \pm 19$ & $463 \pm 13 *(-25)$ & $889 \pm 69$ & $1180 \pm 87^{* * *}(+33)$ \\
\hline Periaqueductal gray & $244 \pm 17$ & $166 \pm 13^{*}(-32)$ & $431 \pm 6$ & $560 \pm 26^{*}(+30)$ \\
\hline Dorsal raphe nucleus & $269 \pm 27$ & $195 \pm 21^{* *}(-28)$ & ND & \\
\hline Locus coeruleus & $370 \pm 23$ & $279 \pm * *(-25)$ & $463 \pm 13$ & $549 \pm 28 * * *(+19)$ \\
\hline Lateral parabrachial nucleus & $357 \pm 19$ & $219 \pm 17^{*}(-39)$ & $644 \pm 11$ & $640 \pm 28$ \\
\hline Nucleus tractus solitarius & $530 \pm 21$ & $400 \pm 33^{* *}(-25)$ & $686 \pm 13$ & $1048 \pm 69^{*}(+35)$ \\
\hline
\end{tabular}

Brain sections were assayed for DAMGO-stimulated $\left[{ }^{35} \mathrm{~S}\right] \mathrm{GTP} \gamma \mathrm{S}$ and $\left[{ }^{3} \mathrm{H}\right]$ naloxone binding as described in Materials and Methods. Data represent nanocuries per gram of $\left[{ }^{35} \mathrm{~S}\right]$ or $\left[{ }^{3} \mathrm{H}\right]$ from densitometric analysis of autoradiograms and are mean values \pm SE of triplicate sections of brains from eight treated and seven control animals. Numbers in parentheses represent percentage change in heroin self-administering animals compared with control. Significantly different from control by Student's $t$ test: *p $\leq 0.005 ; * * p \leq 0.01 ;{ }^{* * *} p \leq 0.05$. ND, Not determined.

groups of animals. Results showed that the effect of chronic heroin self-administration in decreasing $\mu$ receptor-stimulated $\left[{ }^{35} \mathrm{~S}\right] \mathrm{GTP} \gamma \mathrm{S}$ binding varied across brain regions. The largest decreases were observed in brainstem, with $25-39 \%$ reductions in heroin self-administering rats compared with controls. Decreases in $\mu$-stimulated $\left[{ }^{35} \mathrm{~S}\right] \mathrm{GTP} \gamma \mathrm{S}$ binding were also observed in medial thalamus (28\%) and amygdala (32\%). DAMGO-stimulated $\left[{ }^{35} \mathrm{~S}\right] \mathrm{GTP} \gamma \mathrm{S}$ binding also appeared to be reduced in hypothalamus (17\% decrease), but this effect did not reach the level of statistical significance $(p>0.05)$. Although trends of decreased DAMGO-stimulated $\left[{ }^{35} \mathrm{~S}\right] \mathrm{GTP} \gamma \mathrm{S}$ binding were observed in other regions, there were no significant decreases observed in caudate putamen, nucleus accumbens, cingulate cortex, and prefrontal cortex in brains from heroin self-administering rats, with the 


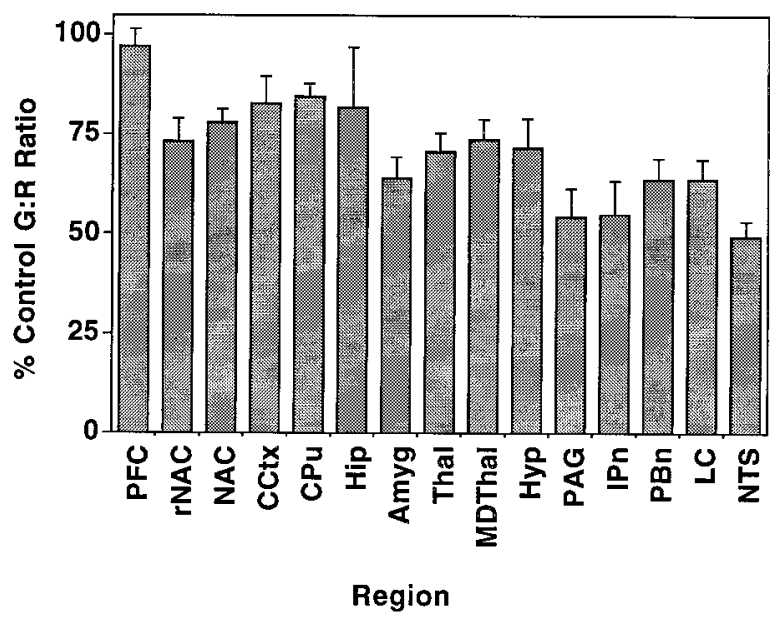

Figure 4. Ratios of DAMGO-stimulated $\left[{ }^{35} \mathrm{~S}\right] \mathrm{GTP} \gamma \mathrm{S}$ binding to $\left[{ }^{3} \mathrm{H}\right.$ ]naloxone binding $(\mathrm{G} / \mathrm{R}$ ratios) in regions from control and heroin self-administering rats, expressed as percentage of values in control animals. Data from both autoradiographic assays (nanocuries per gram for $\left[{ }^{35} \mathrm{~S}\right]$ and $\left.\left[{ }^{3} \mathrm{H}\right]\right)$ were obtained from Table 1 , and ratios of $\left[{ }^{35} \mathrm{~S}\right]$ to $\left[{ }^{3} \mathrm{H}\right]$ were calculated in both control and heroin-treated animals. Ratios (which varied from 0.25 to 1.4 ) were separately obtained in sections from each animal, and data are expressed as mean values \pm SEM. PFC, Prefrontal cortex; $r N A C$, nucleus accumbens rostral pole; $N A C$, nucleus accumbens; $C C t x$, cingulate cortex; $C P u$, caudate putamen; Hip, hippocampus; Amyg, amygdala; Thal, medial thalamus; MDT, medial dorsal thalamus; Hyp, hypothalamus; $P A G$, periaqueductal gray; $I P n$, interpeduncular nucleus; $P B n$, lateral parabrachial nucleus; $L C$, locus coeruleus; $N T S$, commissural nucleus tractus solitarius.

exception of the rostral pole of the nucleus accumbens $(p<$ 0.005 ). Similar results were obtained whether the nucleus accumbens was analyzed as a whole or separated into shell and core regions.

In contrast to the inhibitory effects of chronic heroin selfadministration on $\mu$ opioid receptor-activated G-proteins, increased $\left[{ }^{3} \mathrm{H}\right]$ naloxone binding was observed in several brain regions after chronic heroin self-administration (Table 1). Although the increase in $\left[{ }^{3} \mathrm{H}\right]$ naloxone binding in forebrain was generally small, in some of these areas this increase $(\sim 10 \%)$ was significant (i.e., prefrontal and cingulate cortices, nucleus accumbens, hippocampus). A greater increase (27\%) was seen in hypothalamus, an effect comparable to the increases measured in brainstem nuclei. With the exception of the lateral parabrachial nucleus, increased $\left[{ }^{3} \mathrm{H}\right]$ naloxone binding was found in all of the brainstem nuclei analyzed. In general, the magnitude of the increases in $\left[{ }^{3} \mathrm{H}\right]$ naloxone binding in brainstem $(20-35 \%)$ was greater than those measured in the forebrain.

Table 1 shows that eight of the nine regions with significant decreased $\mu$-stimulated $\left[{ }^{35} \mathrm{~S}\right] \mathrm{GTP} \gamma \mathrm{S}$ binding after chronic heroin self-administration also demonstrated increased $\left[{ }^{3} \mathrm{H}\right]$ naloxone binding. This finding suggests that decreased $\mu$ receptor activation of G-proteins after chronic heroin self-administration occurred despite a significant increase of $\mu$ receptors, indicating a loss in receptor-G-protein coupling efficiency after chronic heroin exposure. To further explore this concept, data from Table 1 were expressed as the ratios between $\mu$-stimulated $\left[{ }^{35} \mathrm{~S}\right] \mathrm{GTP} \gamma \mathrm{S}$ binding and $\left[{ }^{3} \mathrm{H}\right]$ naloxone binding $(\mathrm{G} / \mathrm{R}$ ratios) in each region, in both control and chronic heroin animals. Results (Fig. 4) show that the decrease in $\mu$ receptor activation of G-proteins after chronic heroin self-administration was even more evident when expressed in this manner, with significant decreases in $G / R$ ratios in every region except prefrontal cortex and hippocampus. For example, chronic heroin self-administration produced $35 \%$ decreases in the $\mathrm{G} / \mathrm{R}$ ratio in medial thalamus and amygdala and $40-50 \%$ decreases in brainstem nuclei. These results indicate a significant decline in the efficiency of $\mu$ receptor-G-protein coupling in these regions after chronic heroin self-administration.

\section{Agonist-stimulated $\left[{ }^{35} \mathrm{~S}\right] \mathrm{GTP} \gamma \mathrm{S}$ autoradiography for other receptors}

Receptor-coupled G-protein activity for several other G-proteincoupled receptors was examined in control and heroin selfadministration brains to determine whether other $G_{i} / G_{o}$-coupled receptors were affected by heroin treatment. $\delta$ opioid-stimulated $\left[{ }^{35} \mathrm{~S}\right] \mathrm{GTP} \gamma \mathrm{S}$ binding was of particular interest, because at relatively high concentrations heroin metabolites also bind to $\delta$ opioid receptors. However, no significant differences in $\delta$ opioidstimulated $\left[{ }^{35} \mathrm{~S}\right] \mathrm{GTP} \gamma \mathrm{S}$ binding were found in forebrain regions, including amygdala, nucleus accumbens, caudate putamen, cingulate cortex, and prefrontal cortex (Table 2). There was a trend toward a decrease in $\delta$-stimulated $\left[{ }^{35} \mathrm{~S}\right] \mathrm{GTP} \gamma \mathrm{S}$ binding observed in amygdala, but the variability precluded any significant differences. Nevertheless, the possibility of concerted changes in $\mu$ and $\delta$ receptors in amygdala represents an intriguing possibility, especially considering the recent evidence of opioid receptor heterodimers (Jordan and Devi, 1999). Data from brainstem nuclei were not included in the analysis because the level of $p$-ClDPDPE-stimulated $\left[{ }^{35} \mathrm{~S}\right] \mathrm{GTP} \gamma \mathrm{S}$ binding was too low in these regions to be accurately quantified. Several other G-proteincoupled receptors were also examined using agonist-stimulated $\left[{ }^{35} \mathrm{~S}\right] \mathrm{GTP} \gamma \mathrm{S}$ binding to determine whether the activity of other receptor types was affected by chronic heroin self-administration. However, none of these receptors, including ORL-1, GABA adenosine $A_{1}$, or cannabinoid receptors, showed any changes in G-protein activation (Table 2). In addition, 5- $\mathrm{HT}_{1 \mathrm{~A}}$-stimulated $\left[{ }^{35} \mathrm{~S}\right] \mathrm{GTP} \gamma \mathrm{S}$ binding was examined in dorsal raphe nucleus and hippocampus, but no significant changes were found (data not shown). These data suggest that the desensitization produced by uncoupling $\mu$ opioid receptors from G-proteins in brain is homologous in nature.

\section{DISCUSSION}

The current study used heroin self-administration for 29-39 d to assess the effect of chronic opiate exposure on $\mu$ receptors. The effects of chronic opiate administration have typically been studied using scheduled injections or subcutaneously implanted morphine pellets. The choice of dose, dosing frequency, and route of administration is usually made for practical considerations, rather than behavioral or pharmacological measures made during the dosing regimen. Although these paradigms efficiently produce opiate tolerance and physical dependence, they may not necessarily mimic the gradual development of tolerance and physical dependence that occurs with illicit heroin use in humans, where doses are escalated for subjective effects. In the present study, a paradigm that incorporates this behavior-driven dose escalation has been applied to heroin self-administration in rats.

Desensitization of $\mu$ receptor-activated G-proteins in heroin self-administering rats was observed in brain areas crucial in mediating many of the acute and chronic actions of opiates. These include analgesia (periaqueductal gray, thalamus), respiratory depression and cardiovascular effects [parabrachial nucleus, commissural nucleus tractus solitarius (cNTS)], sympathetic symptoms of withdrawal (locus coeruleus), and emotional responses 
Table 2. Effect of chronic heroin self-administration on agonist-stimulated $\left[{ }^{35} \mathrm{~S}\right] \mathrm{GTP} \gamma \mathrm{S}$ binding in rat brain

\begin{tabular}{lccccc}
\multicolumn{5}{c}{$\%$ Net $\left[{ }^{35} \mathrm{~S}\right] \mathrm{GTP} \gamma \mathrm{S}$ binding in control animals } \\
\cline { 2 - 5 } & Delta & ORL-1 & GABA $_{\mathrm{B}}$ & $\mathrm{A}_{1}$ & $\mathrm{CB}$ \\
\hline Prefrontal cortex & $116 \pm 15$ & $108 \pm 6$ & $88 \pm 9$ & $99 \pm 4$ & $91 \pm 3$ \\
Cingulate cortex & $96 \pm 5$ & $91 \pm 7$ & $115 \pm 4$ & $92 \pm 5$ & $99 \pm 5$ \\
Caudate putamen & $98 \pm 4$ & $\mathrm{ND}$ & $\mathrm{ND}$ & $91 \pm 5$ & $96 \pm 5$ \\
Nucleus accumbens & $96 \pm 5$ & $\mathrm{ND}$ & $\mathrm{ND}$ & $91 \pm 6$ & $\mathrm{ND}$ \\
Amygdala & $84 \pm 13$ & $90 \pm 12$ & $\mathrm{ND}$ & $84 \pm 6$ & $102 \pm 6$ \\
Hippocampus & $\mathrm{ND}$ & $95 \pm 7$ & $\mathrm{ND}$ & $95 \pm 3$ & $102 \pm 3$ \\
Thalamus & $96 \pm 8$ & $92 \pm 16$ & $99 \pm 5$ & $101 \pm 8$ & $\mathrm{ND}$ \\
\hline
\end{tabular}

Brain sections from control and heroin self-administering rats were assayed for agonist-stimulated $\left.{ }^{35} \mathrm{~S}\right] \mathrm{GTP} \gamma \mathrm{S}$ binding as described in Materials and Methods. Receptors (and agonists) included delta opioid ( $p$-CI-DPDPE), ORL-1 (nociceptin/

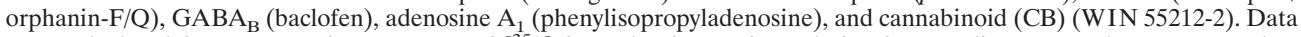
were calculated from nanocuries per gram of $\left[{ }^{35} \mathrm{~S}\right]$ from densitometric analysis of autoradiograms and are expressed as percentage net agonist-stimulated $\left.{ }^{35} \mathrm{~S}\right] \mathrm{GTP} \gamma \mathrm{S}$ binding of control animals using triplicate sections of brains from eight treated and seven control animals. ND, Not determined.

(amygdala). In contrast, nucleus accumbens, which mediates reinforcing effects of several psychoactive drugs including opiates, displayed less desensitization in heroin self-administering rats compared with areas like thalamus, amygdala, and brainstem nuclei. The effect of chronic heroin self-administration in caudate putamen, which mediates some of the motor effects of opiates, was not significant. The decreases found in agonist-stimulated $\left[{ }^{35} \mathrm{~S}\right] \mathrm{GTP} \gamma \mathrm{S}$ binding after heroin self-administration could be caused by a decrease in either agonist potency or efficacy; preliminary results from amygdala membranes suggest that the primary effect of chronic heroin treatment is to decrease agonist efficacy (C. Maher, T. Martin, and S. Childers, unpublished observations).

An important consideration in any study of chronic agonist treatment is whether residual drug remains bound to tissue and affects results in an artifactual manner. This possibility is unlikely for several reasons. First, brain sections were incubated in buffers containing sodium and GDP, which increase agonist dissociation from receptors (Childers and Snyder, 1980) and remove endogenous and exogenous agonists from membranes. Second, residual agonist in sections would increase basal $\left[{ }^{35} \mathrm{~S}\right] \mathrm{GTP} \gamma \mathrm{S}$ binding. In fact, heroin self-administration had no effect on basal $\left[{ }^{35} \mathrm{~S}\right] \mathrm{GTP} \gamma \mathrm{S}$ binding except in two regions, locus coeruleus and interpeduncular nucleus, where basal binding was decreased. Finally, no decreases were seen in $\left[{ }^{3} \mathrm{H}\right]$ naloxone binding in any region. These results, coupled with the fact that the effect of chronic heroin self-administration varied across brain regions, indicate that these effects were not caused by residual heroin in brain sections.

These studies in heroin self-administering rats confirm previous results from rats treated noncontingently with morphine for $12 \mathrm{~d}$ (Sim et al., 1996a). In that study, desensitization of DAMGO-stimulated $\left[{ }^{35} \mathrm{~S}\right] \mathrm{GTP} \gamma \mathrm{S}$ binding was observed only in specific brainstem nuclei, including periaqueductal gray, dorsal raphe nucleus, parabrachial nucleus, locus coeruleus, and cNTS. The present study confirms these effects and shows that heroin self-administration produces the highest level of $\mu$ opioid desensitization in these areas. This confirmation is important, because it was accomplished using a different drug, dose, and administration paradigm. Therefore, these effects on $\mu$ opioid activation of G-proteins appear to be a fundamental response of neurons in these regions to chronic opioid agonist exposure. Interestingly, in the previous study, no effects of chronic morphine treatment were observed in forebrain regions. The finding that chronic heroin self-administration produced $\mu$ receptor desensitization in thalamus and amygdala may be the result of several differences between the two studies, including administration of different opiates (heroin vs morphine) and a longer treatment duration (39 $\mathrm{d}$ of heroin vs $12 \mathrm{~d}$ of morphine). Indeed, the brain levels of total opioid are significantly higher after intravenous administration of heroin compared with morphine, and peak levels are reached more rapidly (Way et al., 1965). There may also be a difference of drug self-administration versus noncontingent administration (Smith et al., 1980).

Another goal of this study was to use $\left[{ }^{3} \mathrm{H}\right]$ naloxone autoradiography under the same assay conditions as $\left[{ }^{35} \mathrm{~S}\right] \mathrm{GTP} \gamma \mathrm{S}$ autoradiography to determine whether changes in $\mu$ receptors accompanied the decrease in receptor-G-protein coupling. A radiolabeled antagonist was used to avoid any changes in agonist high-affinity states that might accompany receptor-G-protein uncoupling. Most regions with decreased DAMGO-stimulated $\left[{ }^{35} \mathrm{~S}\right] \mathrm{GTP} \gamma \mathrm{S}$ binding demonstrated significant increases in $\left[{ }^{3} \mathrm{H}\right]$ naloxone binding. This change in $\left[{ }^{3} \mathrm{H}\right]$ naloxone binding may be the result of changes in binding kinetics; however, this would produce changes in $\left[{ }^{3} \mathrm{H}\right]$ naloxone $K_{\mathrm{D}}$ values, which has not been observed in cell culture studies with chronic agonist treatment (Breivogel et al., 1997).

The $\mathrm{G} / \mathrm{R}$ ratio between agonist-activated G-proteins and receptors showed a greater decrease after chronic heroin selfadministration than $\mu$-stimulated $\left[{ }^{35} \mathrm{~S}\right] \mathrm{GTP} \gamma \mathrm{S}$ binding by itself. Although these results suggest that efficiency of $\mu$ receptor-Gprotein coupling was reduced after chronic heroin selfadministration, the $\mathrm{G} / \mathrm{R}$ ratio should be interpreted with caution: because it does not determine $B_{\max }$ of receptors or agonistactivated G-proteins, it is not equivalent to the amplification factor (Sim et al., 1996b). Indeed, without a precise measure of $B_{\text {max }}$ values, true receptor efficiency cannot be calculated, and the apparent increase in binding observed in the present studies may be produced by changes in receptor affinity. On the other hand, this $\mathrm{G} / \mathrm{R}$ ratio is a relevant measure of efficiency between $\mu$ receptors and activated G-proteins because (1) $\left[{ }^{3} \mathrm{H}\right]$ naloxone, as an antagonist, does not vary in its $K_{\mathrm{D}}$ value at $\mu$ receptors across brain regions (Maher et al., 2000), and (2) DAMGO-stimulated $\left[{ }^{35} \mathrm{~S}\right] \mathrm{GTP} \gamma \mathrm{S}$ binding was determined with saturating concentrations of agonist. The fact that almost all regions with decreased $\mu$-stimulated G-proteins also displayed increased $\mu$ receptor 
binding may indicate an important response of this system to chronic agonist exposure. It is possible that the initial event of receptor-G-protein uncoupling could be accompanied by later increases in receptor synthesis to compensate for receptor desensitization, as described previously for $\beta$-adrenergic receptors (Lefkowitz et al., 1992).

The relationship between changes in $\mu$ receptor binding and development of tolerance/dependence is not clear. Previous studies provided conflicting results regarding the effect of chronic opioid treatment on opioid receptor number, and the data are difficult to interpret because different paradigms were used. Moreover, previous findings of decreased receptor binding in brain after chronic agonist treatment (Yoburn et al., 1993) may in fact be consistent with the present findings: because most previous studies were accomplished with $\left[{ }^{3} \mathrm{H}\right]$ agonist binding, desensitization caused by receptor-G-protein uncoupling would result in a decrease in high-affinity agonist binding with no actual decrease in total receptor number. Interestingly, a previous study using chronic morphine administration with [ $\left.{ }^{3} \mathrm{H}\right] \mathrm{DAMGO}$ autoradiography also reported an increase in $\mu$ receptor binding (Brady et al., 1989). Although data from cell lines indicate that chronic opioid treatment decreases receptor number along with G-protein uncoupling (Puttfarcken et al., 1988; Breivogel et al., 1997), other studies have shown that different opiate agonists have differential effects on receptor phosphorylation (Chakrabarti et al., 1997; Keith et al., 1998) and that morphine (a major metabolite of heroin) does not promote $\mu$ receptor internalization (Keith et al., 1998).

The desensitization in $\mu$-activated G-proteins after chronic heroin self-administration was homologous, because no changes in other receptors coupling to G-proteins were observed. Moreover, less $\mu$ opioid receptor desensitization was found in forebrain regions that may mediate reinforcing behaviors, particularly the nucleus accumbens (Vaccarino et al., 1985). The small magnitude of the effect on $\mu$ opioid-activated G-proteins in these areas may explain why although it is clear that tolerance develops to effects of opiates such as analgesia and respiratory depression, there is controversy regarding the degree of tolerance that develops to the reinforcing and discriminative stimulus effects of opiates (Colpaert, 1995; Contarino et al., 1997).

Chronic heroin self-administration is a complex interplay of a number of effects of opioid agonists, including tolerance, physical dependence, and reinforcement. The large increase in the daily intake of heroin in self-administering animals reflects the dramatic tolerance that develops to this drug, as well as its potent reinforcing properties. Opiate addiction results from both the positive reinforcing effects of opiates as well as avoidance of the negative effects of physical dependence (Schulteis and Koob, 1996). Certainly, the animals in the current study were highly physically dependent, because they experienced withdrawal symptoms if not allowed free access to heroin. Therefore, an important question is which of these facets of chronic opiate effects (tolerance or physical dependence) are mediated by $\mu$ opioid receptor desensitization in specific brain nuclei. The issue of tolerance cannot be addressed at the current time without a careful a time course study. However, the present results may have important implications regarding the development of physical dependence. A number of studies (Kogan et al., 1992) suggest that withdrawal may be associated with increased excitatory tone in specific brain regions, and $\mu$ opioid receptors are predominantly inhibitory in nature (Christie et al., 1987). If $\mu$ receptors are desensitized during chronic agonist exposure, the resulting loss in inhibitory tone may increase excitatory neuronal function in specific brain nuclei and thus contribute to the development of physical dependence. These results suggest that regionally specific adaptations in inhibitory signal transduction may underlie the differential development of opiate dependence.

\section{REFERENCES}

Alt A, Mansour A, Akil H, Medzihradsky F, Traynor JR, Woods JH (1998) Stimulation of guanosine-5'-O-(3-[ ${ }^{35}$ S $]$ thio $)$ triphosphate binding by endogenous opioids acting at a cloned mu receptor. J Pharmacol Exp Ther 286:282-288.

Blasig J, Hollt V, Hengstenberg J, Dum J, Herz A (1979) Noncompetitive nature of the antagonistic mechanism responsible for tolerance to opiate-induced analgesia. Neuropharmacology 18:473-481.

Bozarth MA, Wise RA (1984) Anatomically distinct opiate receptor fields mediate reward and physical dependence. Science 224:516-517.

Brady LS, Herkenham M, Long JB, Rothman RB (1989) Chronic morphine increases $\mu$-opiate receptor binding in rat brain: a quantitative autoradiographic study. Brain Res 477:382-386.

Breivogel CS, Selley DE, Childers SR (1997) Acute and chronic effects of opioids on delta and mu receptor activation of G-proteins in NG108-15 and SK-N-SH cell membranes. J Neurochem 68:1462-1472.

Chakrabarti S, Yang W, Law PY, Loh HH (1997) The mu-opioid receptor down-regulates differently from the delta-opioid receptor: requirement of a high affinity receptor/G protein complex formation. Mol Pharmacol 52:105-113.

Chen Y, Mestek A, Liu J, Hurley JA, Yu L (1993) Molecular cloning and functional expression of a $\mu$-opioid receptor from rat brain. Mol Pharmacol 44:8-12.

Childers SR, Snyder SH (1980) Differential regulation by guanine nucleotides of opiate agonist and antagonist receptor interactions. J Neurochem 34:583-593.

Christie MJ, Williams JT, North RA (1987) Cellular mechanisms of opioid tolerance: studies in single brain neurons. Mol Pharmacol 32:633-638.

Clark MJ, Emmerson PJ, Mansour A, Akil H, Woods JH, Portoghese PS, Remmers AE, Medzihradsky F (1997) Opioid efficacy in a C6 glioma cell line stably expressing the delta opioid receptor. J Pharmacol Exp Ther 283:501-510.

Colpaert FC (1995) Drug discrimination: no evidence for tolerance to opiates. Pharmacol Rev 47:605-629.

Contarino A, Zanotti A, Drago F, Natolino F, Lipartiti M, Giusti P (1997) Conditioned place preference: no tolerance to the rewarding properties of morphine. Naunyn Schmiedebergs Arch Pharmacol 355:589-594

Evans CJ, Keith Jr DE, Morrison H, Magendzo K, Edwards RH (1992) Cloning of a delta opioid receptor by functional expression. Science 258:1952-1955.

Goldstein A, Herrera J (1995) Heroin addicts and methadone treatment in Albuquerque: a 22-year follow-up. Drug Alcohol Dep 40:139-150.

Herkenham M, Pert CB (1982) Light microscopic localization of brain opiate receptors: a general autoradiographic method which preserves tissue quality. J Neurosci 2:1129-1149.

Inturrisi CE, Schultz M, Shin S, Umans JG, Angel L, Simon EJ (1983) Evidence from opiate binding studies that heroin acts through its metabolites. Life Sci 33:773-776.

Jordan BA, Devi LA (1999) G-protein-coupled receptor heterodimerization modulates receptor function. Nature 399:697-700.

Keith DE, Anton B, Murray SR, Zaki PA, Chu PC, Lissin DV, Monteillet-Agius G, Stewart PL, Evans CJ, von Zastrow M (1998) mu-Opioid receptor internalization: opiate drugs have differential effects on a conserved endocytic mechanism in vitro and in the mammalian brain. Mol Pharmacol 53:377-384.

Kieffer BL, Befort K, Gaveriaux-Ruff C, Hirth CG (1992) The $\delta$-opioid receptor: isolation of a cDNA by expression cloning and pharmacological characterization. Proc Natl Acad Sci USA 89:12048-12052.

Klee WA, Streaty RA (1974) Narcotic receptor sites in morphinedependent rats. Nature 248:61-63.

Kogan JH, Nestler EJ, Aghajanian GK (1992) Elevated basal firing rates and enhanced responses to 8-Br-cAMP in locus coeruleus in brain slices from opiate-dependent rats. Eur J Pharmacol 211:47-53.

Law PY, Hom DS, Loh HH (1983) Opiate receptor down-regulation and desensitization in neuroblastoma $\mathrm{x}$ glioma NG108-15 hybrid cells 
are two separate cellular adaptation processes. Mol Pharmacol 24:413-424.

Lefkowitz RJ, Inglese J, Koch WJ, Pitcher J, Attramadal H, Caron MG (1992) G-protein-coupled receptors: regulatory role of receptor kinases and arrestin proteins. Cold Spring Harbor Symp Quant Biol 57:127-133.

Maher C, Selley D, Childers S (2000) Relationship of mu opioid receptor binding to activation of G-proteins in specific rat brain regions. Biochem Pharmacol 59:1395-1401.

Martin TJ, Dworkin SI, Smith JE (1995) Alkylation of mu opioid receptors by $\beta$-funaltrexamine in vivo: comparison of the effects on in situ binding and heroin self-administration in rats. J Pharmacol Exp Ther 272:1135-1140.

Nestler EJ (1992) Molecular mechanisms of drug addiction. J Neurosci 12:2439-2450.

Noble F, Cox BM (1996) Differential desensitization of mu- and deltaopioid receptors in selected neural pathways following chronic morphine treatment. Br J Pharmacol 117:161-169.

Noble F, Cox BM (1997) The role of dopaminergic systems in opioid receptor desensitization in nucleus accumbens and caudate putamen of rat after chronic morphine treatment. J Pharmacol Exp Ther 283:557-565.

Puttfarcken PS, Cox BM (1989) Morphine-induced desensitization and downregulation at mu-receptors in $7315 \mathrm{C}$ pituitary tumor cells. Life Sci 45:1937-1942.

Puttfarcken PS, Werling LL, Cox BM (1988) Effects of chronic morphine exposure on opioid inhibition of adenylyl cylcase in $7315 \mathrm{c}$ cell membranes: a useful model for the study of tolerance at mu opioid receptors. Mol Pharmacol 33:520-527.

Rossi CG, Leventhal L, Pan YX, Cole J, Su W, Bodnar RJ, Pasternak GW (1997) Antisense mapping of MOR-1 in rats: distinguishing between morphine and morphine-6 $\beta$-glucuronide antinociception. J Pharmacol Exp Ther 281:109-114.

Schuller AG, King MA, Zhang J, Bolan E, Pan YX, Morgan DJ, Chang A, Czick ME, Unterwald EM, Pasternak GW, Pintar JE (1999) Retention of heroin and morphine- 6 beta-glucuronide analgesia in a new line of mice lacking exon 1 of MOR-1. Nat Neurosci 2:151-156.

Schulteis G, Koob GF (1996) Reinforcement processes in opiate addiction: a homeostatic model. Neurochem Res 21:1437-1454.

Selley DE, Nestler EJ, Breivogel CS, Childers SR (1997a) Opioid receptor-coupled G-proteins in rat locus coeruleus membranes: decrease in activity after chronic morphine treatment. Brain Res 746:10-18.

Selley DE, Sim LJ, Xiao R, Liu Q, Childers SR (1997b) Mu opioid receptor-stimulated $\left[{ }^{35} \mathrm{~S}\right] \mathrm{GTP} \gamma \mathrm{S}$ binding in rat thalamus and cultured cell lines: signal transduction mechanisms underlying agonist efficacy. Mol Pharmacol 51:87-96.

Selley DE, Liu Q, Childers SR (1998) Signal transduction correlates of mu opioid agonist intrinsic efficacy: receptor-stimulated $\left[{ }^{35} \mathrm{~S}\right] \mathrm{GTP} \gamma \mathrm{S}$ binding in mMOR-CHO cells and rat thalamus. J Pharmacol Exp Ther 285:496-505.
Sim LJ, Selley DE, Childers SR (1995) In vitro autoradiography of receptor-activated G-proteins in rat brain by agonist-stimulated guanylyl $5^{\prime}-\left[\gamma-\left[{ }^{35} S\right]\right.$ thio $]$-triphosphate binding. Proc Natl Acad Sci USA 92:7242-7246.

Sim LJ, Selley DE, Dworkin SI, Childers SR (1996a) Effects of chronic morphine administration on mu opioid receptor-stimulated $\left[{ }^{35} \mathrm{~S}\right]$ GTP $\gamma \mathrm{S}$ autoradiography in rat brain. J Neurosci 16:2684-2692.

Sim LJ, Selley DE, Xiao R, Childers SR (1996b) Differences in G-protein activation by mu and delta opioid, and cannabinoid, receptors in rat striatum. Eur J Pharmacol 307:95-107.

Sim LJ, Xiao R, Childers SR (1996c) Identification of opioid receptorlike (ORL1) peptide-stimulated $\left[{ }^{35} \mathrm{~S}\right] \mathrm{GTP} \gamma \mathrm{S}$ binding in rat brain. NeuroReport 7:729-733.

Sim LJ, Selley DE, Childers SR (1997) Autoradiographic visualization in brain of receptor-G-protein coupling using $\left[{ }^{35} \mathrm{~S}\right] \mathrm{GTP} \gamma \mathrm{S}$ binding. In: Methods in molecular biology: receptor signal transduction protocols (Challiss RS, ed), pp 117-132. Totowa, NJ: Humana.

Smith J, Co C, Freeman M, Sands M, Lane J (1980) Neurotransmitter turnover in rat striatum is correlated with morphine self-administration. Nature 287:152-154.

Tao P-L, Law P-Y, Loh HH (1987) Decrease in delta and mu opioid receptor binding capacity in rat brain after chronic etorphine treatment. J Pharmacol Exp Ther 240:809-816.

Tao P-L, Chang L-R, Chou Y-P, Law P-Y, Loh HH (1993) Chronic opioid treatment may uncouple opioid receptors and G-proteins: evidence from irradiation inactivation analysis. Eur $\mathrm{J}$ Pharmacol 246:233-238.

Thompson RC, Mansour A, Akil H, Watson SJ (1993) Cloning and pharmacological characterization of a rat $\mu$ opioid receptor. Neuron 11:903-913.

Traynor JR, Nahorski SR (1995) Modulation by $\mu$-opioid agonists of guanosine- $5^{\prime}-\mathrm{O}-\left(3-\left[{ }^{35} \mathrm{~S}\right]\right.$ thio $)$ triphosphate binding to membranes from human neuroblastoma SH-SY5Y cells. Mol Pharmacol 47:848-854.

Umans JG, Inturrisi CE (1981) Pharmacodynamics of subcutaneously administered diacetylmorphine, 6-acetylmorphine and morphine in mice. J Pharmacol Exp Ther 218:409-415.

Vaccarino FJ, Bloom FE, Koob GF (1985) Blockade of nucleus accumbens opiate receptors attenuates intravenous heroin reward in the rat. Psychopharmacology 86:37-42.

Way EL, Young JM, Kemp JW (1965) Metabolism of heroin and its pharmacologic implications. Bull Narcotics 17:25-33.

Way EL, Loh HH, Shen FH (1969) Simultaneous quantitative assessment of morphine tolerance and physical dependence. J Pharmacol Exp Ther 167:1-8.

Yoburn BC, Billings B, Duttaroy A (1993) Opioid receptor regulation in mice. J Pharmacol Exp Ther 265:314-320.

Young WS, Kuhar MJ (1979) A new method for receptor autoradiography: $\left[{ }^{3} \mathrm{H}\right]$ opioid receptors in rat brain. Brain Res 179:255-270. 